\title{
Tinjauan Kondisi Fisik (Vo2max) Pada Komunitas Pencinta Basket Paal 5 Jambi
}

\section{Overview Of Physical Conditions (Vo2max) In The Paal 5 Basketball Love Community Of Jambi}

\author{
Boy Indrayana*, Mhd Usni Zamzami Hasibuan \\ FKIP, Universitas Jambi, Jl. Jambi-Muara Bulian KM. 15, Mendalo Darat, Jambi, 36361, Indonesia \\ e-mail:boy.indrayana@yahoo.co.id*,zamzamihsb16@unja.ac.id.
}

\begin{abstract}
Abstrak
Tujuan penelitian ini adalah untuk mengetahui kondisi fisik komunitas pencinta basket paal 5 Jambi dengan kondisi yang ada tanpa memberikan perlakuan sebelumnya. Penelitian ini merupakan jenis penelitian deskriptif. Penelitian ini secara khusus memiliki tujuan untuk mengetahui tingkat kondisi fisik setiap individu yang bermain basket pada komunitas basket secara rutin di malam hari yakni berkenaan dengan daya tahan aerobic (VO2Max). Instrumen penelitian yang digunakan adalah tes MFT (Multi Fitness Test). Populasi yang digunakan dalam penelitian ini adalah seluruh anggota dari komunitas pencinta basket paal 5 sebanyak 20 orang. Berdasarkan hasil tes yang dilakukan, diperoleh hasil tes daya tahan aerobic (VO2Max) dengan rata-rata dari seluruh individu 35,35 dan sesuai norma standarisasi masuk dalam kategori sedang. Hasil rata-rata yang didapatkan dari masing-masing individu menunjukkan bahwa kondisi fisik komunitas pencinta basket tersebut masuk dalam kategori sedang. Hasil ini memberikan makna bahwa untuk mencapai kondisi fisik yang baik perlu dilakukan latihan peningkatan daya tahan aerobic serta latihan-latihan daya tahan lainnya secara rutin dan berkesinambungan.
\end{abstract}

Kata kunci: kondisi fisik, komunitas pencinta basket, analisis deskriptif, pendidikan jasmani

\section{Abstract}

The purpose of this study was to determine the physical condition of the paal 5 Jambi basketball lover community with the existing conditions without giving prior treatment. This research is a type of descriptive research. This study specifically aims to determine the level of physical condition of each individual who plays basketball in the basketball community regularly at night, which is related to aerobic endurance (VO2Max). The research instrument used was the MFT (Multi Fitness Test) test. The population used in this study were all members of the paal 5 basketball lover community as many as 20 people. Based on the results of the tests carried out, the results of the aerobic endurance test (VO2Max) were obtained with an average of 35.35 for all individuals and according to standardized norms, it was in the medium category. The average results obtained from each individual indicate that the physical condition of the basketball lover community is in the moderate category. These results mean that in order to achieve good physical condition it is necessary to carry out aerobic endurance training and other endurance exercises on a regular basis.

Keywords: physical condition, basketball lovers community, analysis descriptive, sport education

corresponding author: boy.indrayana@yahoo.co.id

Artikel Info:

Submitted: 21/09/2021

Revised : 15/10/2021

Accepted : 04/11/2021

Published: 15/11/2021

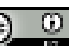




\section{A. Pendahuluan}

Olahraga merupakan bagian dari aktivitas sehari-hari manusia yang berguna membentuk jasmani dan rohani yang sehat (Widodo, 2018). Sampai saat ini olahraga telah memberikan kontribusi yang positif dan nyata bagi peningkatan kesehatan masyarakat (Widodo, 2018). Selain itu olahraga juga turut berperan dalam peningkatan kemampuan bangsa dalam melaksanakan sistem pengembangan yang berkelanjutan (Pasaribu, 2019). Olahraga saat ini juga merupakan sebuah kebutuhan didalam hidup manusia, sama halnya manusia membutuhkan makanan untuk kelangsungan hidupnya begitu pula manusia membutuhkan olahraga atau aktivitas fisik untuk selalu bugar agar bisa menjalankan hari-hari dengan baik (Puspita et al., 2018). Untuk saat ini banyak sekali orang-orang yang hanya menghabiskan separuh hidupnya untuk berkerja dan tidak pernah menyempatkan waktu untuk berolahraga. Sehingga menurut WHO Indonesia merupakan urutan 6 besar di Asia, penduduknya meninggal diakibatkan kurang gerak. Hal ini tentu sangat memprihatinkan sekali kalau hal semacam ini terus berlanjut (Allen et al., 2019).

Dalam melakukan aktivitas olahraga seseorang juga harus memiliki kondisi fisik yang baik sehingga mampu melakukan aktivitas olahraga yang dilakukannya tanpa mengalami kelelahan yang berlebihan, sebaliknya apabila seseorang memiliki kondisi fisik yang kurang baik apalagi buruk maka seseorang akan kesulitan dalam melakukan aktivitas olahraga tersebut sehingga menyebabkan kelelahan yang berlebihan (Arwih, 2019). Menurut (Arwih, 2019) kondisi fisik secara umum merupakan kemampuan dasar untuk mengembangkan kemampuan prestasi tubuh yang terdiri dari komponen kekuatan, kecepatan, daya tahan dan kelentukan.

Berdasarkan observasi dikomunitas Pencinta Basket Paal 5 Jambi merupakan salah satu komunitas basket yang ada di Kota Jambi. Hal ini dapat dibuktikan dengan jadwal rutin bermain basket komunitas tersebut. Melalui survei yang dilakukan di lapangan basket paal 5, perlu dilakukan penelitian untuk mengetahui kondisi fisik setiap individu yang bermain basket secara rutin di malam hari yang mana rata-rata pemain basket yang mengisi kegiatan malam harinya dengan bermain bola basket tersebut adalah individu yang bekerja dari pagi sampai sore hari. Alasan mereka bermain basket pada malam hari karena mereka tidak bisa menyempatkan olahraga dipagi hari 
maupun sore hari.

Menurut para ahli olahraga malam sangat baik dilakukan pada malam hari karena bermanfaat untuk meningkatkan kualitas tidur dan sangat efektif dalam pembentukan otot. Olahraga dimalam hari harus menyesuaikan kapasitas tubuh manusia dan tidak boleh berlebihan. Untuk meningkatkan kualitas tidur sebaiknya tidak dianjurkan berolahraga mendekati jam tidur atau berolahraga terlalu malam (Puspitasari, 2019). Jika berolahraga terlalu malam maka akan mengalami sulit tidur dan olahraga yang dipilih pun harus olahraga yang tidak berat. Hal ini memikirkan kegiatan yang telah kita lakukan seharian tanpa istirahat, apabila kita melakukan kegiatan atau berolahraga yang berat bukan kebugaran jasmani yang kita dapat malah daya tahan tubuh akan menjadi lemah dan membuat seseorang menjadi rentan terhadap penyakit, seperti flu atau demam. Untuk mengetahui seseorang atau atlet dikatakan bugar dapat dilakukan MFT (Multistage Fitrness Test) yang dilakukan dengan menggunakan Bleep test yaitu lari level yang memakai musik saat melakukannya (Saputra \& Aziz, 2020). Tujuan tes ini dilakukan adalah untuk mengetahui kondisi fisik dalam hal ini VO2Max atau kapasitas paru-paru dari pemain basket yang berlatih dimalam hari ini berada dikategori dan level berapa. Semakin banyak level yang dilewati maka semakin baik kebugaran jasmani yang dmiliki pemain basket tersebut (Palmizal et al., 2020).

Penerapan fisik merupakan salah satu faktor yang sangat penting dalam latihan untuk mencapai suatu prestasi yang tinggi (Los Arcos \& Martins, 2018). ( $\underline{\text { Los Arcos \& }}$ Martins, 2018) mengemukakan kondisi fisik dalam olahraga adalah semua kemampuan jasmani yang menentukan prestasi yang realisasinya dilakukan melalui kemampuan pribadi. Kondisi fisik merupakan program pokok untuk pembinaan atlet untuk berprestasi dalam suatu cabang olahraga (Puspitasari, 2019). Menurut (Kusuma \& Setyawati, 2016) kondisi fisik salah satu prasarat yang sangat diperlukan dalam setiap usaha peningkatan prestasi seorang atlit, bahkan dikatakan dasar landasan titik tolak suatu awalan olaraga prestasi. Bedasarkan pendapat para ahli dapat dikemukakan bahwa kondisi fisik merupakan semua kemampuan jasmani yang menentukan prestasi yang realisasinya dilakukan melalui kemampuan pribadi. Kemampuan awal kondisi fisik merupakan ukuran/pedoman untuk membuat perencanaan latihan. Suatu analisa keadaan awal secara umum 
terhadap hasil-hasil pertandingan yang lalu diperlukan untuk mengembangkan prestasi dalam masa-masa kompetisi.

Secara umum kondisi fisik yang diperlukan dalam masing-masing olahraga adalah sama, artinya setiap cabang olahraga memerlukan kondisi fisik dalam usaha mencapai yang optimal, begitu pula dalam olahraga Futsal (Gunawan et al., 2016). Seorang atlet dapat dikatakan dalam keadaan kondisi fisik yang baik apabila ia mampu melakukan aktivitas yang dibebankan kepadanya atau yang dilakukannya tanpa kelelahan yang berlebihan.

Pendapat diatas mengemukakan bahwa kondisi fisik memegang peranan yang sangat penting untuk mempertahankan atau meningkatkan tingkat kesegaran jasmani. Apabila tingkat kesegaran jasmani seorang atlet dalam kondisi yang baik maka untuk penerapan teknik dan taktik dalam permainan akan mudah dikuasai serta gerakan yang dilakukan efektif dan efisien.

Menurut (Gunawan et al., 2016) kondisi fisik merupakan kemampuan dasar untuk mengembangkan kemampuan prestasi tubuh yang terdiri dari komponen kekuatan, kecepatan, daya tahan dan kelentukan. (Putri et al., 2020) mengatakan bahwa latihan kondisi fisik umum berarti latihan-latihan yang beranekaragam untuk mengembangkan kemampuan prestasi tubuh dan merupakan dasar untuk meningkatkan kemampuan kondisi fisik khusus.

Kemampuan tersebut meliputi kekuatan umum, kecepatan umum, daya tahan umum dan kelentukan umum. (Sari, 2018) menjelaskan latihan fisik umum terdiri dari latihan dasar yang beragam, dengan kata lain pelatihan yang mencakup seluruh aspek fisik yang bertujuan pelatihan yang harmonis dan meningkatkan sistem kardio pulmalis (jantung, peredaran darah), kekuatan otot dan ruang gerak sendi yang merupakan dasar, hampir semua cabang olahraga.

Bentuk latihan merupakan suatu fundamen fisik dalam setiap cabang olaraga. Ini berarti bahwa latihan kondisi fisik umum diperlukan untuk semua cabang olaraga. (Jariono et al., 2020) kondisi fisik khusus adalah merupakan kemampuan yang langsung dikaitkan dengan kebutuhan suatu cabang olahraga tertentu. (Putri et al., 2020) mengartikan kondisi khusus sebagai suatu latihan yang optimal dari kemampuan kondisi yang menentukan prestasi suatu cabang olahraga.

Dari pendapat diatas bahwa kondisi fisik khusus menunjukkan kekhususan suatu cabang olahraga, karena kebutuhan terhadap kemampuan ini akan berbeda antara satu cabang http://ejurnal.ubharajaya.ac.id/index.php/JCESPORTS 
olahraga dengan cabang olahraga yang lain. Dengan kata lain, setiap cabang olahraga atau disiplin tertentu membutuhkan kemampuan kondisi fisik khusus sendiri dan spesifik.

Daya tahan merupakan salah satu elemen kondisi fisik yang terpenting, karena dasar dari elemen-elemen kondisi fisik yang lain (Prakoso \& Sugiyanto, 2017). (Warni et al., 2017) mengemukakan daya tahan adalah keadaan atau kondisi tubuh yang mampu berlatih untuk waktu yang lama, tanpa mengalami kelelahan yang berlebihan setelah menyelesaikan latihan tersebut. Menurut (Ardiansyah \& Nasrullah, 2017) daya tahan adalah kesanggupan bekerja dengan intensitas tertentu dalam rentang waktu yang cukup lama, tanpa kelelahan yang berlebihan. Sedangkan menurut (Sari, 2018) daya tahan adalah hasil kemampuan individu untuk memelihara gerakannya dalam kurun waktu tertentu.

Dari pendapat para ahli di atas maka dapat disimpulkan bahwa daya tahan adalah hasil kemampuan organisme pemain untuk mengatasi kelelahan yang timbul setelah melakukan aktivitas tubuh olahraga dalam waktu yang lama. Daya tahan yang dimaksud adalah daya tahan Volume Oxygen Maximal (VO2max).

\section{B. Metode Penelitian}

Penelitian ini menggunakan metode deskriptif dengan menjelaskan secara sistematis dan akurat fakta yang tergambar secara detail dilapangan. Didalam penelitian ini, akan diungkapkan secara detail mengenai kondisi fisik (VO2Max) Komunitas Pencinta Basket Paal 5 Jambi.

Penelitian ini akan dilaksanakan di lapangan basket paal 5 Jambi pada bulan April sampai dengan September 2021. Populasi dalam penelitian ini adalah komunitas pencinta basket paal 5 jambi. Teknik pengambilan sampel pada penelitian ini adalah dengan menggunakan teknik Total Sampling yaitu seluruh anggota komunitas pencinta basket paal 5 yang berjumlah 20 orang akan menjadi sampel pada penelitian ini.

Penelitian ini menggunakan instrumen tes pengukuran MFT (Multi Fitness Test) yang mana tes tersebut dilakukan untuk mendapatkan data tentang kondisi fisik komunitas Pencinta Basket Paal V. Pelaksanaan tes dapat dilakukan dengan beberapa orang sekaligus, hanya saja yang mencatat hasil tes harus tepat dalam setiap tahapan pada kemampuan masing-masing peserta tes. Berikut adalah mekanisme pelaksanaan tes MFT yaitu :

1. Hidupkan Pengeras Suara yang
berisikan Panduan Tes MFT


2. Peserta berdiri dibelakang garis yang telah ditentukan.

3. Peserta berlari dengan di awali bunyi Beep sejauh 20 meter dan harus tiba digaris akhir sebelum bunyi Beep selanjutnya. Jika peserta 2 kali tidak sampai garis setelah bunyi beep, maka akan dihentikan dan yang terakhir dicatat menjadi hasil tes.

Tabel 1 Kategori Standarisasi Daya Tahan Aerobik ( VO2max )

\begin{tabular}{ll}
\hline Kategori & $(\mathrm{VO} 2 \mathrm{max})$ \\
\hline Baik Sekali & $>51,6$ \\
\hline Baik & $42,6-51,5$ \\
\hline Sedang & $33,8-42,5$ \\
\hline Kurang & $25,0-33,7$ \\
\hline Kurang Sekali & $<25,0$ \\
\hline $\begin{array}{l}\text { Sumber : (Pasaribu, 2020) Tes dan Pengukuran } \\
\text { Olahraga }\end{array}$
\end{tabular}

Berdasarkan tujuan dari penelitian, maka pengujian data yang telah diperoleh akan dianalisis menggunakan statistik deskriptif yaitu dengan cara mendeskripsikan hasil penelitian yang diperoleh dari berbagai pengukuran ( tes ) terhadap tingkat kondisi fisik dan analisis yang menggunakan rumus seperti dikemukakan Sudjana sebagai berikut:

$$
\mathrm{P}=\mathrm{f} / \mathrm{n} \times 100 \%
$$

Keterangan :

$$
\begin{aligned}
& \mathrm{P}=\text { persentase } \\
& \mathrm{F}=\text { frekuensi (skor yang diperoleh) } \\
& \mathrm{N}=\text { jumlah sampel tes }
\end{aligned}
$$

\section{Hasil dan Pembahasan}

Hasil

Data yang diperoleh sebagai hasil penelitian adalah data hasil tes yang didapatkan melalui pelaksanaan tes MFT tanpa ada diberikan perlakuan sebelumnya kepada komunitas pencinta basket Paal 5 Jambi. Data yang ada pada tabel adalah kondisi apa adanya orang yang bermain basket dari komunitas pencinta basket tersebut. Berikut adalah tabel hasil tes MFT atau bleep test yang sudah dikonversi berdasarkan kategori standarisasi daya

\begin{tabular}{|c|c|c|c|c|}
\hline No & Item Tes & Lev/blk & Oksigen & Kategori \\
\hline 1 & Res 1 & 6,8 & 35,7 & $\mathrm{~S}$ \\
\hline 2 & Res 2 & 7,2 & 37,1 & S \\
\hline 3 & Res 3 & 5,8 & 32,5 & $\mathrm{~K}$ \\
\hline 4 & Res 4 & 6,1 & 33,2 & $\mathrm{~K}$ \\
\hline 5 & Res 5 & 8,3 & 40,8 & $\mathrm{~S}$ \\
\hline 6 & Res 6 & 6,2 & 33,6 & $\mathrm{~K}$ \\
\hline 7 & Res 7 & 5,3 & 30,6 & $\mathrm{~K}$ \\
\hline 8 & Res 8 & 4,9 & 29,7 & $\mathrm{~K}$ \\
\hline 9 & $\operatorname{Res} 9$ & 4,7 & 28,9 & $\mathrm{~K}$ \\
\hline 10 & Res 10 & 7,8 & 39,2 & $\mathrm{~S}$ \\
\hline 11 & Res 11 & 8,2 & 40,5 & S \\
\hline 12 & Res 12 & 6,9 & 36 & $\mathrm{~S}$ \\
\hline 13 & Res 13 & 6,5 & 34,6 & S \\
\hline 14 & Res 14 & 7,1 & 36,7 & $\mathrm{~S}$ \\
\hline 15 & Res 15 & 7,3 & 37,4 & S \\
\hline 16 & Res 16 & 6,4 & 34,3 & $\mathrm{~S}$ \\
\hline 17 & Res 17 & 8,1 & 40,2 & $\mathrm{~S}$ \\
\hline 18 & Res 18 & 7,5 & 38,1 & $\mathrm{~S}$ \\
\hline 19 & Res 19 & 6,6 & 35 & $S$ \\
\hline 20 & Res 20 & 5,9 & 32,9 & $\mathrm{~S}$ \\
\hline
\end{tabular}
tahan aerobic (VO2Max).

Tabel 2 Data Hasil MFT/ Bleep Test Komunitas Pencinta Basket Paal 5 Jambi

Berdasarkan tabel diatas dapat dilihat bahwa hasil tes MFT dari komunitas 
pencinta basket tersebut terbagi atas 2 kategori yang telah disesuaikan dengan norma standarisasi daya tahan aerobik yaitu kategori sedang dan kurang. Ada 6 orang dari komunitas tersebut yang masuk dalam kategori kurang dan 14 orang masuk dalam kategori sedang.

Dari hasil penelitian, yakni mulai dari pengambilan data di lapangan dengan melakukan tes MFT tanpa diawali dengan atau diberikan perlakuan sebelum tes, maka yang menjadi acuan sebagai pembahasan hasil penelitian adalah sebagai berikut : Berdasarkan tinjauan kondisi fisik VO2Max yang dilakukan kepada komunitas pencinta basket paal 5 Jambi melalui tes MFT, hasil rata-rata yang didapatkan dari masing-masing individu menunjukkan bahwa kondisi fisik komunitas pencinta basket tersebut masuk dalam kategori sedang dengan rata-rata nilai 35,35 sesuai dengan kategori standarisasi daya tahan aerobik yang tertera di atas.

\section{Pembahasan}

Sesuai dengan tujuan yang ingin dicapai yakni untuk melihat kondisi fisik individu yang melakukan aktifitas olahraga bola basket pada saat malam hari dapat diketahui bahwa gambaran hasil kondisi fisik individu yang melakukan aktifitas fisik pada malam hari sesuai dengan norma tes masuk dalam kategori sedang. Orang yang beraktifitas fisik atau berolahraga pada malam hari berdasarkan hasil tes menunjukkan bahwa kondisi fisik mereka tidaklah dalam kondisi yang baik atau tidak juga dalam kategori kurang.

Hasil penelitian ini juga sesuai dengan penelitian yang dilakukan oleh (Setia \& Winarno, 2021) yang menyatakan bahwa daya tahan otot berada pada kategori kurang. Hal senada juga dilakukan oleh (Nizam et al., 2020) yang menunjukkan hasil bahwa daya tahan yang dimiliki oleh atlet bola basket berkategori sedang. Berdasarkan hasil sumber-sumber relevan dan hasil dari penelitian dapat diketahui faktor yang menyebabkan kondisi fisik pemain bola basket berada pada kategori sedang yakni banyaknya pemain bola basket yang jarang melakukan latihan serta rutin. Dengan demikian untuk meningkatkan kondisi fisik pada pemain bola basket dapat dilakukan dengan melakukan latihan daya tahan secara rutin dan berkesinambungan.

\section{Kesimpulan}

Berdasarkan hasil tes MFT yang dilakukan terhadap komunitas pencinta basket didapatkan hasil yaitu 6 orang berada dalam kategori kurang dan 14 orang dalam kategori sedang dengan nilai rata-rata 35,35 dikategorikan sedang. Dapat disimpulkan setelah melakukan 
tinjauan kondisi fisik VO2Max kepada komunitas pencinta basket bahwa kondisi VO2Max tidak berada dalam kategori kurang dan kategori baik.

\section{Daftar pustaka}

Allen, C. P., Telford, R. M., Telford, R. D., \& Olive, L. S. (2019). Sport, physical activity and physical education experiences: Associations with functional body image in children. Psychology of Sport and Exercise, $\quad 45$ (August), 101572. https://doi.org/10.1016/j.psychsport.2 $\underline{019.101572}$

Ardiansyah, M., \& Nasrullah, N. (2017). Analisis Tingkat Daya Tahan Kardiorespirasi Wasit Sepakbola Di Palembang Tahun 2017. Jurnal Prestasi, 1(2), 35-40. https://doi.org/10.24114/jp.v1i2.8064 Arwih, M. Z. (2019). Hubungan Kelincahan Dengan Kemampuan Menggiring Pada Permainan Bolabasket Mahasiswa Jurusan Ilmu Keolahragaan Angkatan 2017 FKIP UHO. Jurnal Ilmu Keolahragaan, Fakultas Ilmu Keolahragaan, UNiversitas Negeri Medan, 18(1), 63-71.

https://doi.org/10.24114/jik.v18i1.143 $\underline{13}$

Gunawan, Y. R., Suherman, A., \& Sudirjo, E. (2016). Hubungan Kecepatan Dan
Kelincahan Terhadap Kemampuan Dribbling Bola Futsal Pada Atlet O2Sn Kecamatan Sumedang Utara. SpoRTIVE, $\quad 1(1), \quad 1-12$. https://ejournal.upi.edu/index.php/Sp oRTIVE/article/view/3413

Jariono, G., Nursubekti, N., Indarto, P., Hendarto, S., Nugroho, H., \& Fachrezy, F. (2020). Analisis kondisi fisik menggunakan software Kinovea pada atlet taekwondo Dojang Mahameru Surakarta. Transformasi: Jurnal Pengabdian Masyarakat, 16(2), 133-144. https://doi.org/10.20414/transformasi. $\underline{v 16 i 2.2635}$

Kusuma, B. A., \& Setyawati, H. (2016). Survei Faktor-Faktor yang Mempengaruhi Minat Olahraga Rekreasi Akhir Pekan di Alun-Alun Wonosobo. Journal of Physical Education, Sport, Health and Recreations, 5(2), 68-73. https://doi.org/10.15294/active.v5i2.1 $\underline{0737}$

Los Arcos, A., \& Martins, J. (2018). Physical Fitness Performance of Young Professional Soccer Players Does Not Change During Several Training Seasons in a Spanish Elite Reserve Team: Club Study, 19962013. Journal of Strength and Conditioning Research, 32(9), 25772583.

http://ejurnal.ubharajaya.ac.id/index.php/JCESPORTS 
https://doi.org/10.1519/JSC.00000000 $\underline{00002426}$

Nizam, I., Rahmat, Z., \& Munzir. (2020). Evaluasi Daya Tahan Atlet Basket SMK Negeri 1 Banda Aceh Dengan menggunakan Metode Beep Test. Jurnal Ilmiah Mahasiswa Pendidikan, $\quad 1(1), \quad 12-15$. https://www.jim.bbg.ac.id/pendidikan /article/download/29/21

Palmizal, A., Munar, H., Muchlisin, A., \& Pasaribu, N. (2020). Kemampuan Vo2max Atlet Sepakbola Ditinjau dari Latihan. Journal Coaching Education Sports, 1(1), 27-36. https://doi.org/10.31599/jces.v1i1.83

Pasaribu, A. M. N. (2019). Peranan senam irama terhadap kebugaran jasmani untuk siswa sekolah dasar. Jurnal SPORTIF: Jurnal Penelitian Pembelajaran, 5(1), 89-97. https://doi.org/10.29407/js_unpgri.v5i $\underline{1.12551}$

Pasaribu, A. M. N. (2020). Tes dan Pengukuran Olahraga. YPSIM.

Prakoso, G. P. W., \& Sugiyanto, F. (2017). Pengaruh Metode Latihan dan Daya Tahan Otot Tungkai terhadap Hasil Peningkatan Kapasitas Vo 2 max Pemain Bola Basket. Jurnal Keolahragaan, 5(2), 151-160. https://doi.org/10.21831/jk.v5i2.1017 $\underline{7}$
Puspita, D., Calista, W., \& Suyadi, S. (2018). Perkembangan Fisik-Motorik Siswa Usia Dasar: Masalah Dan Perkembangannya. JIP: Jurnal Ilmiah PGMI, 4(2), 170-182. https://doi.org/10.19109/jip.v4i2.2780 Puspitasari, N. (2019). Faktor Kondisi Fisik Terhadap Resiko Cedera Olahraga Pada Permainan Sepakbola. Jurnal Fisioterapi Dan Rehabilitasi, $3(1)$, 54-71.

https://doi.org/10.33660/jfrwhs.v3i1.3 $\underline{4}$

Putri, A. E., Donie, Fardi, A., \& Yenes, R. (2020). Metode Circuit Training Dalam Peningkatan Daya Ledak Otot Tungkai dan Daya Ledak Otot Lengan Bagi Atlet Bolabasket. Jurnal Patriot, Jurusan Kepelatihan, Fakultas Ilmu Keolahragaan, UNiversitas Negeri Padang, 2(3), 680-691.

https://doi.org/10.24036/patriot.v2i3.

$\underline{661}$

Saputra, N., \& Aziz, I. (2020). Tinjauan Tingkat Kondisi Fisik Pemain Bolavoli Putra Sma 2 Pariaman. Performa Olahraga, 5(1), 39-47. https://doi.org/10.24036/jpo137019

Sari, V. I. P. (2018). Daya Tahan Kekuatan Otot Lengan dan Koordinasi Mata Tangan Dengan Ketepatan Tembakan Bebas Peserta Ekstrakurikuler 
Bolabasket Putri SMAN 1 Pekanbaru.

Jurnal Bola (Bersama Olahraga Laju

Asia), 1(1), 23-33.

Setia, D. Y., \& Winarno, M. E. (2021).

Survei Tingkat Kebugaran Jasmani

Tim Bola Basket. Sport Science and

Health, 3(3), 107-116.

https://doi.org/10.17977/um062v3i32

$\underline{021 \mathrm{p} 107-116}$

Warni, H., Arifin, R., \& Bastian, R. A. (2017). Pengaruh Latihan Daya

Tahan (Endurance) Terhadap

Peningkatan Vo2max Pemain

Sepakbola. Multilateral: Jurnal

Pendidikan Jasmani Dan Olahraga,

16(2), 121-126.

https://doi.org/10.20527/multilateral.v $\underline{16 \mathrm{i} 2.4248}$

Widodo, A. (2018). Makna Dan Peran

Pendidikan Jasmani Dalam

Pembentukan Insan. Jurnal Motion,

9(1), 53-60.

https://www.researchgate.net/publicat

ion/329442726_MAKNA_DAN_PE

RAN_PENDIDIKAN_JASMANI_D

ALAM_PEMBENTUKAN_INSAN

YANG_MELEK JASMANIAHTER

-LITERASI_JASMANIAHNYA 